\title{
Room-Temperature Fluoride Shuttle Batteries Based on a Fluorohydrogenate Ionic Liquid Electrolyte
}

\section{$\operatorname{AUTHOR}(\mathrm{S})$ :}

Yamamoto, Takayuki; Matsumoto, Kazuhiko; Hagiwara, Rika; Nohira, Toshiyuki

\section{CITATION:}

Yamamoto, Takayuki ...[et al]. Room-Temperature Fluoride Shuttle Batteries Based on a Fluorohydrogenate Ionic Liquid Electrolyte. ACS Applied Energy Materials 2019, 2(9): 61536157

ISSUE DATE:

2019-09-23

URL:

http://hdl.handle.net/2433/261770

\section{RIGHT:}

This is the accepted manuscript of the article, which has been published in final form at https://doi.org/10.1021/acsaem.9b01260.; この論文は出版社版でありません。引用の際 には出版社版をご確認ご利用ください。; This is not the published version. Please cite only the published version. 
Room-temperature fluoride shuttle batteries based on a fluorohydrogenate ionic liquid electrolyte

Takayuki Yamamoto, ${ }^{1,}$ Kazuhiko Matsumoto, ${ }^{2}$ Rika Hagiwara, ${ }^{2}$ and Toshiyuki Nohira $^{1, *}$

${ }^{1}$ Institute of Advanced Energy, Kyoto University, Gokasho, Uji 611-0011, Japan

${ }^{2}$ Graduate School of Energy Science, Kyoto University, Yoshida-honmachi, Sakyo-ku, Kyoto 606-8501, Japan

${ }^{*}$ Corresponding Authors:

*E-mail: $\quad$ yamamoto.takayuki.2w@kyoto-u.ac.jp, $\quad$ Tel: $\quad+81-774-38-3498, \quad$ Fax: +81-774-38-3499 (T. Y.).

*E-mail: $\quad$ nohira.toshiyuki.8r@kyoto-u.ac.jp, $\quad$ Tel: $\quad+81-774-38-3500, \quad$ Fax: +81-774-38-3499 (T. N.).

\section{KEYWORDS}

fluoride shuttle battery, fluorohydrogenate ionic liquid, positive electrode, copper fluoride, full utilization 


\begin{abstract}
Fluoride shuttle batteries (FSBs) are attracting considerable interests as next-generation energy storage devices, owing to their superior energy density. We focused on fluorohydrogenate ionic liquids (FHILs) as new electrolytes for FSBs operating at room temperature, because they show much higher ionic conductivities compared with those of conventional electrolytes. In the present study, the chargedischarge behavior of $\mathrm{CuF}_{2}$ positive electrodes was investigated in the $\left[\mathrm{C}_{2} \mathrm{C}_{1} \mathrm{im}\right]\left[(\mathrm{FH})_{2.3} \mathrm{~F}\right]\left(\mathrm{C}_{2} \mathrm{C}_{1}\right.$ im $=1$-ethyl-3-methylimidazolium $) \mathrm{FHIL}$ at $298 \mathrm{~K}$. The $\mathrm{CuF}_{2}$ electrode exhibited an initial discharge capacity of ca. $500 \mathrm{mAh}\left(\mathrm{g}-\mathrm{CuF}_{2}\right)^{-1}$, which is close to the theoretical capacity, $528 \mathrm{mAh}\left(\mathrm{g}-\mathrm{CuF}_{2}\right)^{-1}$.
\end{abstract}




\section{INTRODUCTION}

The widespread use of various kinds of electronic devices results in an increasing demand for rechargeable batteries. In particular, the markets of large-scale batteries for stationary use and electric vehicles are growing rapidly, and lithium-ion batteries (LIBs) are being introduced in these applications. However, the energy densities of conventional LIBs, based only on topotactic reactions, are currently limited to $250 \mathrm{Wh}$ $\mathrm{kg}^{-1}{ }^{1}$ To overcome this limitation, batteries operating via completely novel reactions are required. Fluoride shuttle batteries (FSBs) are among the potential candidates that can be used for this purpose. ${ }^{2}$ In these batteries, metals or metal fluorides work as active materials according to the following reactions:

$$
\begin{array}{ll}
\text { (Positive electrode) } & \mathrm{MF}_{x}+x \mathrm{e}^{-} \rightleftharpoons \mathrm{M}+x \mathrm{~F}^{-} \\
\text {(Negative electrode) } & (x / y) \mathrm{M}^{\prime}+x \mathrm{~F}^{-} \rightleftharpoons(x / y) \mathrm{M}^{\prime} \mathrm{F}_{y}+x \mathrm{e}^{-}
\end{array}
$$

where $\mathrm{M}=\mathrm{Co}, \mathrm{Cu}$, etc. and $\mathrm{M}^{\prime}=\mathrm{Mg}, \mathrm{Al}$, etc. Although monovalent anions are involved in the electrochemical reactions, multi-electron reactions occur for most active materials, resulting in extremely high theoretical energy densities.

The development of electrolytes is one of the most important tasks for the fabrication of practical FSBs. The physicochemical properties of inorganic solid electrolytes exhibiting fluoride ion conduction have been investigated for several decades. ${ }^{3-8}$ According to Fichtner et al., with $\mathrm{La}_{1-x} \mathrm{Ba}_{x} \mathrm{~F}_{3-x}$ solid electrolyte, copper- and bismuth-based fluorides show a charge-discharge capacity of more than $100 \mathrm{mAh} \mathrm{g}^{-1}$. However, most of the solid electrolytes require operating temperatures higher than 423 $\mathrm{K}$ because of their low ionic conductivities at room temperature, leading to a limited applications. Recently, several new electrolytes potentially suitable for room-temperature FSBs have been reported. ${ }^{9-12}$ Although the discharge (defluorination) 
reaction of $\mathrm{a} \mathrm{BiF}_{3}$ positive electrode occurred in a polymer electrolyte containing bifluoride ions $\left(\mathrm{FHF}^{-}\right)$, the charge (fluorination) reaction was not confirmed. ${ }^{9}$ The reversible charge-discharge behavior of bismuth fluoride in an ionic liquid ${ }^{10}$ and in organic solvent-based electrolytes ${ }^{11,12}$ were also reported. Copper-based compounds are more attractive as positive electrode materials, because they possess higher theoretical capacities than those of bismuth-based ones (e.g., $528 \mathrm{mAh}\left(\mathrm{g}-\mathrm{CuF}_{2}\right)^{-1}$ for $\mathrm{CuF}_{2}$ and $302 \mathrm{mAh}\left(\mathrm{g}-\mathrm{BiF}_{3}\right)^{-1}$ for $\left.\mathrm{BiF}_{3}\right)$. Moreover, the redox potential of the $\mathrm{CuF}_{2} / \mathrm{Cu}$ couple is ca. $0.3 \mathrm{~V}$ higher than that of $\mathrm{BiF}_{3} / \mathrm{Bi}$. However, the capacities reported in previous studies are limited to ca. $300 \mathrm{mAh}\left(\mathrm{g}-\mathrm{CuF}_{2}\right)^{-1}$ with solid electrolytes at $423 \mathrm{~K} .^{6,7}$ Moreover, in the case of liquid electrolytes, the capacities are less than $100 \mathrm{mAh}$ $\left(\mathrm{g}-\mathrm{CuF}_{2}\right)^{-1}$ at room temperature. ${ }^{12}$ Thus, achieving full utilization of the theoretical capacity of $\mathrm{CuF}_{2}$ at room temperature is a worthwhile challenge, whose resolution requires the development of a new electrolyte.

Our groups have previously focused on fluorohydrogenate ionic liquids (FHILs) as electrolytes for electrochemical devices. ${ }^{13-18}$ The most noteworthy feature of FHILs is the fluorohydrogenate anion, $(\mathrm{FH})_{n} \mathrm{~F}^{-}$, which produces particularly high ionic conductivities. ${ }^{13}$ For example, the $\left[\mathrm{C}_{2} \mathrm{C}_{1} \mathrm{im}\right]\left[(\mathrm{FH})_{2.3} \mathrm{~F}\right]$ ionic liquid $\left(\mathrm{C}_{2} \mathrm{C}_{1}\right.$ im $=$ 1-ethyl-3-methylimidazolium) exhibits an ionic conductivity as high as $100 \mathrm{mS} \mathrm{cm}^{-1}$ at $298 \mathrm{~K}^{15}$ Since the ionic conductivities of conventional electrolytes based on organic solvents ${ }^{12}$ and ionic liquids ${ }^{10}$ are less than $5 \mathrm{mS} \mathrm{cm}^{-1}$ at $298 \mathrm{~K}$, FHILs possess superior properties as battery electrolytes on this point. The structures of the imidazolium cation and fluorohydrogenate anion are shown in Figure 1. We have previously reported the performances of electrochemical capacitors with FHIL electrolytes, ${ }^{16-18}$ in which activated carbon is involved in the redox reactions and fluorohydrogenate anions act as 
fluoride ion carriers. Thus, we expect that FHILs can represent good candidates as electrolytes of FSBs operating at ambient temperature. In the present study, we propose fluorohydrogenate ionic liquids as novel FSB electrolytes and report the electrochemical behavior of copper-based positive electrodes in a $\left[\mathrm{C}_{2} \mathrm{C}_{1} \mathrm{im}\right]\left[(\mathrm{FH})_{2.3} \mathrm{~F}\right]$ ionic liquid at $298 \mathrm{~K}$. The remarkably high ability of this electrolyte as fluoride ion carrier enables the full utilization of the theoretical capacity of $\mathrm{CuF}_{2}$.

\section{EXPERIMENTAL SECTION}

The $\left[\mathrm{C}_{2} \mathrm{C}_{1} \mathrm{im}\right]\left[(\mathrm{FH})_{2.3} \mathrm{~F}\right]$ fluorohydrogenate ionic liquid was prepared by the reaction of $\left[\mathrm{C}_{2} \mathrm{C}_{1} \mathrm{im}\right] \mathrm{Cl}$ with anhydrous HF. ${ }^{14,15}$ A three-electrode cell (EC Frontier Co., Ltd.) was used for the electrochemical measurements. The $\mathrm{CuF}_{2}$ or $\mathrm{Cu}$ composite films on platinum mesh current collector were used as working electrode. The $\mathrm{CuF}_{2}$ composite film was composed of $\mathrm{CuF}_{2}$ (Alfa Acer, purity 99.5\%), acetylene black (AB; Strem Chemicals), and polytetrafluoroethylene (PTFE; Aldrich) with a weight ratio of $80 / 10 / 10$. These three reagents were mixed and grinded in a mortar, and then the obtained composite film was pressed on platinum mesh. According to the scanning electron microscopy (SEM) image of the surface in Figure $\mathrm{S} 1$, the particle sizes of $\mathrm{CuF}_{2}$ are distributed within the range of 100-200 $\mathrm{nm}$. The $\mathrm{Cu}$ composite film was prepared by similar method using metallic copper ( $5 \mu \mathrm{m} \phi$; Kojundo Chemical Laboratory Co., Ltd.), $\mathrm{AB}, \mathrm{PTFE}$ powders, and their weight ratio was $80 / 10 / 10$. Both the reference and counter electrodes are mixed composites of $\mathrm{CuF}_{2}$ and metallic copper, which is consisted of $\mathrm{CuF}_{2}$, metallic copper, $\mathrm{AB}$, and PTFE. The weight ratio was 50/35/10/5. A two-ply PTFE filter (Omnipore ${ }^{\mathrm{TM}}$, Millipore, thickness: $65 \mu \mathrm{m}$, average pore diameter: $0.45 \mu \mathrm{m}$, porosity: $80 \%$ ) was used as a separator. All electrodes and PTFE filters were immersed 
in the electrolyte prior to the test.

Cyclic voltammetry and charge-discharge tests were conducted using electrochemical measurement apparatus (HZ-7000 or HZ-Pro, Hokuto Denko Corp.). All measurements were performed at $298 \mathrm{~K}$. Charge-discharge tests were started after cyclic voltammetry test for 3 cycles at a scan rate of $10 \mathrm{mV} \mathrm{s}^{-1}$. Detailed conditions are provided in the text or figure captions. Other experimental conditions are described in detail in the Supporting Information.

\section{RESULTS AND DISCUSSION}

Figure $2 \mathrm{a}$ shows typical cyclic voltammograms of $\mathrm{CuF}_{2}$ electrodes in the $\left[\mathrm{C}_{2} \mathrm{C}_{1} \mathrm{im}\right]\left[(\mathrm{FH})_{2.3} \mathrm{~F}\right]$ ionic liquid electrolyte at $298 \mathrm{~K}$. In the first cycle, during the cathodic sweep, the reduction current rapidly increases starting from $-0.1 \mathrm{~V}$ vs. $\mathrm{CuF}_{2} / \mathrm{Cu}$, which is attributed to the reduction (defluorination) reaction of $\mathrm{CuF}_{2}$ to metallic copper. An oxidation peak is observed in the following scan toward positive potential, suggesting the fluorination of metallic copper. The possible electrochemical reaction of $\mathrm{CuF}_{2}$ can be expressed as follows by considering the anionic species in the electrolyte:

$$
\mathrm{CuF}_{2}+4\left[(\mathrm{FH})_{3} \mathrm{~F}\right]^{-}+2 \mathrm{e}^{-} \rightleftharpoons \mathrm{Cu}+6\left[(\mathrm{FH})_{2} \mathrm{~F}\right]^{-}
$$

Moreover, the cyclic voltammograms in the second and third cycles overlap with each other, indicating that stable defluorination/fluorination reactions are expected to occur in the present ionic liquid. Figure $2 \mathrm{~b}$ displays the initial charge-discharge curve after the cyclic voltammetry measurements at $298 \mathrm{~K}$. A single plateau is observed in the discharge (defluorination) process, and the obtained discharge capacity is $517 \mathrm{mAh}$ $\left(\mathrm{g}-\mathrm{CuF}_{2}\right)^{-1}$, which corresponds to as high as $98 \%$ of the theoretical capacity of $\mathrm{CuF}_{2}$ 
$\left(528 \mathrm{mAh}\left(\mathrm{g}-\mathrm{CuF}_{2}\right)^{-1}\right)$. In the subsequent charge process, the capacity reaches $475 \mathrm{mAh}$ $\left(\mathrm{g}-\mathrm{CuF}_{2}\right)^{-1}$, which is markedly higher than the values obtained in previous studies using inorganic solid ${ }^{6,7}$ and liquid ${ }^{12}$ electrolytes. The resulting Coulombic efficiency (= $\left.C_{\text {Charge }} / C_{\text {Discharge }} \times 100\right)$ is $92 \%$, where $C_{\text {Charge }}$ and $C_{\text {Discharge }}$ are capacities in the charge and discharge processes, respectively. Although the capacity decreases at higher chargedischarge rates, charge capacities of ca. 300 and $200 \mathrm{mAh}\left(\mathrm{g}-\mathrm{CuF}_{2}\right)^{-1}$ are maintained at rates of 0.1 and $0.2 \mathrm{C}$, respectively (Figure $\mathrm{S} 2$ ). Cycleability of the $\mathrm{CuF}_{2}$ electrode is also investigated as shown in Figure S3. In this cell, the 1st and 10th charge (fluorination) capacities at $0.05 \mathrm{C}$ rate are 432 and $264 \mathrm{mAh}\left(\mathrm{g}-\mathrm{CuF}_{2}\right)^{-1}$, respectively, Thus, the capacity retention $\left(=C_{\text {Charge }(10 \text { th })} / C_{\text {Charge }(1 \mathrm{st})} \times 100\right)$ is calculated to be $61 \%$. The obtained capacities in the 10th cycle are much higher than those in the organic-solvent electrolytes at $298 \mathrm{~K},{ }^{12}$ and are comparable to those in the solid electrolyte at $423 \mathrm{~K}{ }^{7}$

To confirm the charge-discharge reactions represented by equation (3), $\mathrm{CuF}_{2}$ electrodes in various charge-discharge states were prepared and analyzed by X-ray diffraction (XRD) and X-ray photoelectron spectroscopy (XPS). Figure 3 summarizes the XRD patterns for the (a) pristine, (b) half-discharged, (c) fully discharged, (d) half-charged, and (e) fully charged $\mathrm{CuF}_{2}$ electrodes. The charge-discharge curves of the $\mathrm{CuF}_{2}$ electrodes used for the $\mathrm{XRD}$ analysis are shown in Figure $\mathrm{S} 4$. In the half-discharged electrode (pattern (b) in Figure 3), the diffraction peaks of $\mathrm{CuF}_{2}$ decrease in intensity while those of metallic copper appear, indicating the $\mathrm{CuF}_{2}$ defluorination reaction. This reaction proceeds until the end of the discharge (pattern (c)), when the intensities of the $\mathrm{CuF}_{2}$ diffraction peaks further decrease and those of the peaks corresponding to metallic copper increase. As shown in patterns (d) and (e), the peak intensities of metallic copper keep decreasing throughout the charging process, 
corresponding to the fluorination of metallic copper. On the other hand, the $\mathrm{CuF}_{2}$ peaks do not increase during the charging process, implying the formation of an amorphous phase.

To further investigate the products of the charging reaction, the surfaces of the electrodes were analyzed by XPS (Figure 4). In the pristine electrode (spectrum (a)), the broad peak observed at binding energies around $937 \mathrm{eV}$ is ascribed to photoelectrons from the $\mathrm{Cu} 2 \mathrm{p}_{3 / 2}$ orbital of $\mathrm{CuF}_{2}$. The peak of metallic copper at $932 \mathrm{eV}$ appears in the half-discharged state (spectrum (b)), while the $\mathrm{CuF}_{2}$ peak is fully converted to the metallic copper peak at the end of the discharge (spectrum (c)). Thus, the surface of the $\mathrm{CuF}_{2}$ electrode is completely defluorinated, forming metallic copper. The small $\mathrm{CuF}_{2}$ peak detected in the XRD pattern (Figure 3c) suggests that a small amount of $\mathrm{CuF}_{2}$ in the inner region of the electrode has remained unreacted. During the charge process (spectrum (d)), the intensity of the peak at $932 \mathrm{eV}$ decreases and the broad peak at around $937 \mathrm{eV}$ appears again. Finally, the peaks of metallic copper disappear at the end of the charging process (spectrum (e)), which indicates that eventually the surface of the electrode completely transforms into $\mathrm{CuF}_{2}$. In addition, we investigated the charging behavior of the metallic copper electrode. Despite a charge capacity of $242 \mathrm{mAh}$ $(\mathrm{g}-\mathrm{Cu})^{-1}$, which is lower than the theoretical capacity of $844 \mathrm{mAh}(\mathrm{g}-\mathrm{Cu})^{-1}$ (Figure S5), the XPS analysis clearly confirms the fluorination of metallic copper on the electrode surface (Figure S6).

In most previous studies, ${ }^{6,7,12}$ even using nanoparticles smaller than $100 \mathrm{~nm}$, the theoretical capacity of $\mathrm{CuF}_{2}$ was not achieved, and the charge (fluorination) capacities were likely to be much lower than the discharge (defluorination) ones. This is because $\mathrm{CuF}_{2}$ is known to be an electric insulator ${ }^{19}$ and the surface of metallic copper particles is 
covered with $\mathrm{CuF}_{2}$ during the charging process, which hinders further fluorination reactions. On the other hand, in the $\left[\mathrm{C}_{2} \mathrm{C}_{1} \mathrm{im}\right]\left[(\mathrm{FH})_{2.3} \mathrm{~F}\right]$ ionic liquid electrolyte, $\mathrm{CuF}_{2}$ exhibits high capacities (close to the theoretical ones) in both charging and discharging processes. To understand these effects, we focused on the solubility of $\mathrm{CuF}_{2}$ in the $\left[\mathrm{C}_{2} \mathrm{C}_{1} \mathrm{im}\right]\left[(\mathrm{FH})_{2.3} \mathrm{~F}\right]$ ionic liquid. If a small amount of $\mathrm{CuF}_{2}$ is dissolved into the electrolyte, continuous electrochemical fluorination of metallic copper is expected to be achieved. According to the results of inductively coupled plasma-atomic emission spectroscopy (ICP-AES) measurements for the $\left[\mathrm{C}_{2} \mathrm{C}_{1} \mathrm{im}\right]\left[(\mathrm{FH})_{2.3} \mathrm{~F}\right]$ ionic liquid saturated with $\mathrm{CuF}_{2}$ (Supporting Information), the concentration of copper is ca. 100 $\operatorname{ppm}\left(=\mathrm{mg} \mathrm{dm}^{-3}\right)$, which corresponds to a molar concentration of $1.6 \times 10^{-3}(\mathrm{~mol}-\mathrm{Cu})$ $\mathrm{dm}^{-3}$. Since the average volume of the $\left[\mathrm{C}_{2} \mathrm{C}_{1} \mathrm{im}\right]\left[(\mathrm{FH})_{2.3} \mathrm{~F}\right]$ ionic liquid used in the electrochemical cells is ca. $4 \times 10^{-4} \mathrm{dm}^{3}$, the amount of $\mathrm{CuF}_{2}$ dissolved in $\left[\mathrm{C}_{2} \mathrm{C}_{1} \mathrm{im}\right]\left[(\mathrm{FH})_{2.3} \mathrm{~F}\right]$ is calculated to be $6.5 \times 10^{-2} \mathrm{mg}$, according to the following equation:

$$
W_{\mathrm{CuF}_{2} \text { (Sol) }}=C_{\mathrm{Cu} \text { (ICP-AES) }} \times V_{\text {Electrolyte }} \times M_{\mathrm{CuF}_{2}}
$$

where $W_{\mathrm{CuF}_{2} \text { (Sol) }}$ is the mass of $\mathrm{CuF}_{2}$ dissolved in the electrolyte, $C_{\mathrm{Cu} \text { (ICP-AES) }}$ is the concentration of copper determined by the ICP-AES analysis, $V_{\text {Electrolyte }}$ is the volume of electrolyte in the electrochemical cell, and $M_{\mathrm{CuF}_{2}}$ is the formula weight of $\mathrm{CuF}_{2}$, respectively. The possible chemical dissolution reactions of $\mathrm{CuF}_{2}$ are expressed as follows:

$$
\begin{aligned}
& \mathrm{CuF}_{2}+2\left[(\mathrm{FH})_{2} \mathrm{~F}\right]^{-} \rightarrow\left[\mathrm{CuF}_{4}\right]^{2-}+4 \mathrm{HF} \\
& \mathrm{CuF}_{2}+2\left[(\mathrm{FH})_{2} \mathrm{~F}\right]^{-} \rightarrow\left[\mathrm{CuF}_{4}(\mathrm{FH})_{2}\right]^{2-}+2 \mathrm{HF}
\end{aligned}
$$

In reaction (5-A), the resulting HF can momentarily interact with $\left[(\mathrm{FH})_{2} \mathrm{~F}\right]^{-}$to produce $\left[(\mathrm{FH})_{3} \mathrm{~F}\right]^{-}$. The $\left[\mathrm{CuF}_{4}\right]^{2-}$ anion was previously found in several compounds, such as 
$\mathrm{K}_{2} \mathrm{CuF}_{4}$ and $\mathrm{Cs}_{2} \mathrm{CuF}_{4} .^{20,21}$ Because $\mathrm{Cu}(\mathrm{II})$ in these compounds is octahedrally coordinated by two terminal and four corner-shared $\mathrm{F}$ atoms, $\left[\mathrm{CuF}_{4}(\mathrm{FH})_{2}\right]^{2-}$ is another possible species. Moreover, as the average weight of $\mathrm{CuF}_{2}$ in the working electrode is $2.0 \mathrm{mg}$, approximately $3 \%$ of loaded $\mathrm{CuF}_{2}$ can be dissolved in the electrolyte. Thus, the small amount of dissolved $\mathrm{CuF}_{2}$ may undergo the so-called direct dissolution/deposition reaction.

$$
\begin{aligned}
& {\left[\mathrm{CuF}_{4}\right]^{2-}+2 \mathrm{e}^{-} \rightleftharpoons \mathrm{Cu}+4 \mathrm{~F}^{-}} \\
& {\left[\mathrm{CuF}_{4}(\mathrm{FH})_{2}\right]^{2-}+2 \mathrm{e}^{-} \rightleftharpoons \mathrm{Cu}+4 \mathrm{~F}^{-}+2 \mathrm{HF}}
\end{aligned}
$$

For both (6-A) and (6-B) reactions, the resulting $\mathrm{F}^{-}$and $\mathrm{HF}$ can form $\left[(\mathrm{FH})_{n} \mathrm{~F}\right]^{-}$by further reacting with $\mathrm{HF}$ or $\mathrm{F}^{-}$, respectively. However, this reaction cannot be the dominant one because no color change is observed in the electrolyte even after full charge. In general, a copper(II) solution shows a blue color when the ion concentration becomes higher than around $500 \mathrm{ppm}$. In addition, although the dissolved form of $\mathrm{CuF}_{2}$ can be tentatively assigned to $\left[\mathrm{CuF}_{4}\right]^{2-}$ or $\left[\mathrm{CuF}_{4}(\mathrm{FH})_{2}\right]^{2-}$, the chemical identification of this species is rather difficult due to its low concentration, and this aspect is still under investigation.

Based on the results above, because most of the $\mathrm{CuF}_{2}$ in the electrode remains solid during the charge-discharge processes, it is obvious that the overall reaction corresponds to equation (3), i.e., to the defluorination/fluorination reactions between $\mathrm{CuF}_{2}$ and metallic copper. However, it is also reasonable to assume that the chemical dissolution of the $\mathrm{CuF}_{2}$ produced during the charging process and its re-precipitation on the electrode surface occur simultaneously (equation (5)), because the electrolyte in the vicinity of the electrode surface is likely to be saturated with $\mathrm{CuF}_{2}$. If the $\mathrm{CuF}_{2}$ formed by the charging reaction partly dissolves in the electrolyte, the naked metallic copper 
reappears and is rapidly fluorinated. The dissolved copper species would continuously precipitate on the other parts of the electrode surface. In this way, the repetition of these electrochemical/chemical process enables the reaction to take place throughout the deep core of the copper particles, leading to the full utilization of the active materials.

\section{CONCLUSIONS}

In the present study, we proposed a new electrolyte, fluorohydrogenate ionic liquid $\left[\mathrm{C}_{2} \mathrm{C}_{1} \mathrm{im}\right]\left[(\mathrm{FH})_{2.3} \mathrm{~F}\right]$, for room-temperature fluoride shuttle batteries. The high ionic conductivity of this ionic liquid makes it very attractive as fluoride-ion conductor. Using this electrolyte, the theoretical capacities were almost achieved at room temperature, and the defluorination/fluorination reactions of $\mathrm{CuF}_{2}$ were confirmed by XRD and XPS analyses. In particular, the charging process of metallic copper proceeds through the combination of chemical dissolution and re-precipitation of the produced $\mathrm{CuF}_{2}$, which is a key factor for overcoming the intrinsic limitations associated with the poor electric conductivity of metal fluorides.

\section{ASSOCIATED CONTENT}

\section{Supporting Information}

The Supporting Information is available on the journal website at DOI: $\operatorname{xxxxxxxxxxxxx.}$

Detailed experimental conditions, FE-SEM image of $\mathrm{CuF}_{2}$ electrode, additional charge-discharge curves, electrochemical behavior of metallic copper electrodes, and XPS spectra (PDF). 


\section{AUTHOR INFORMATION}

\section{Corresponding Authors}

*E-mail: yamamoto.takayuki.2w@kyoto-u.ac.jp (T. Y.).

*E-mail: nohira.toshiyuki.8r@kyoto-u.ac.jp (T. N.).

\section{ORCID}

Takayuki Yamamoto: 0000-0003-3553-3272

Kazuhiko Matsumoto: 0000-0002-0770-9210

Rika Hagiwara: 0000-0002-7234-3980

Toshiyuki Nohira: 0000-0002-4053-554X

\section{Author Contributions}

T. Y. performed the electrochemical measurements/analyses and wrote the manuscript. K. M and R. H. prepared the ionic liquid electrolyte. T. N. designed and supervised the whole study.

\section{ACKNOWLEDGMENTS}

This study was supported by Research and Development Initiative for Scientific Innovation of New Generation Batteries 2 (RISING2) project of the New Energy and Industrial Technology Development Organization (NEDO), Japan.

\section{REFERENCES}

(1) Whittingham, M. S. Ultimate Limits to Intercalation Reactions for Lithium Batteries. Chem. Rev. 2014, 114, 11414-11443. 
(2) Gschwind, F.; Rodriguez-Garcia, G.; Sandbeck, D. J. S.; Gross, A.; Weil, M.; Fichtner, M.; Hörmann, N. Fluoride ion batteries: Theoretical performance, safety, toxicity, and a combinatorial screening of new electrodes. J. Fluorine Chem. 2016, $182,76-90$.

(3) Kennedy, J. H.; Miles, R.; Hunter, J. Solid Electrolyte Properties and Crystal Forms of Lead Fluoride. J. Electrochem. Soc. 1973, 120, 1441-1446.

(4) Schoonman, J. A Solid-State Galvanic Cell with Fluoride-Conducting Electrolytes. J. Electrochem. Soc. 1976, 123, 1772-1775.

(5) Schoonman, J.; Wolfert, A. Solid-state galvanic cells with fast fluoride conducting electrolytes. Solid State Ionics 1981, 3-4, 373-379.

(6) Reddy, M. A.; Fichtner, M. Batteries based on fluoride shuttle. J. Mater. Chem. 2011, 21, 17059-17062.

(7) Thieu, D. T.; Fawey, M. H.; Bhatia, H.; Diemant, T.; Chakravadhanula, V. S. K.; Behm, R. J.; Kübel, C.; Fichtner, M. $\mathrm{CuF}_{2}$ as Reversible Cathode for Fluoride Ion Batteries. Adv. Funct. Mater. 2017, 27, 1701051.

(8) Grenier, A.; Porras-Gutierrez, A.-G.; Groult, H.; Beyer, K. A.; Borkiewicz, O. J.; Chapman, K. W.; Dambournet, D. Electrochemical reactions in fluoride-ion batteries: mechanistic insights from pair distribution function analysis. J. Mater. Chem. A 2017, 5, 15700-15705.

(9) Gschwind, F.; Zao-Karger, Z.; Fichtner, M. A fluoride-doped PEG matrix as an electrolyte for anion transportation in a room-temperature fluoride ion battery. $J$. Mater. Chem. A 2014, 2, 1214-1218.

(10) Okazaki, K.; Uchimoto, Y.; Abe, T.; Ogumi, Z. Charge-Discharge Behavior of Bismuth in a Liquid Electrolyte for Rechargeable Batteries Based on a Fluoride 
Shuttle. ACS Energy Lett. 2017, 2, 1460-1464.

(11) Konishi, H.; Minato, T; Abe, T., Ogumi, Z. Electrochemical Performance of a Bismuth Fluoride Electrode in a Reserve-Type Fluoride Shuttle Battery. J. Electrochem. Soc. 2017, 164, A3702-A3708.

(12) Davis, V. K.; Bates, C. M.; Omichi, K.; Savoie, B. M.; Momčilović, N.; Xu, Q.; Wolf, W. J.; Webb, M. A.; Billings, K. J.; Chou, N. H.; Alayoglu, S.; McKenney, R. K.; Darolles, I. M.; Nair, N. G.; Hightower, A.; Rosenberg, D.; Ahmed, M.; Brooks, C. J.; Miller III, T. F.; Grubbs, R. H.; Jones, S. C. Room-temperature cycling of metal fluoride electrodes: Liquid electrolytes for high-energy fluoride ion cells. Science 2018, 362, 1144-1148.

(13) Enomoto, T.; Nakamori, Y.; Matsumoto, K.; Hagiwara, R. Ion-Ion Interactions and Conduction Mechanism of Highly Conductive Fluorohydrogenate Ionic Liquids. J. Phys. Chem. C 2011, 115, 4324-4332.

(14) Hagiwara, R.; Hirashige, T.; Tsuda, T.; Ito, Y. Acidic 1-ethyl-3-methylimidazolium fluoride: a new room temperature ionic liquid. $J$. Fluorine Chem. 1999, 99, 1-3.

(15) Hagiwara, R.; Hirashige, T.; Tsuda, T.; Ito, Y. A Highly Conductive Room Temperature Molten Fluoride: EMIF-2.3HF. J. Electrochem. Soc. 2002, 149, D1D6.

(16) Ue, M.; Takeda, M.; Toriumi, A; Kominato, A.; Hagiwara, R.; Ito, Y. Application of Low-Viscosity Ionic Liquid to the Electrolyte of Double-Layer Capacitors. J. Electrochem. Soc. 2003, 150, A499-A502.

(17) Senda, A.; Matsumoto, K.; Nohira, T.; Hagiwara, R. Effects of the cationic structures of fluorohydrogenate ionic liquid electrolytes on the electric double 
layer capacitance. J. Power Sources 2010, 195, 4414-4417.

(18) Taniki, R.; Matsumoto, K.; Nohira, T.; Hagiwara, R. Evaluation of Double-Layer and Redox Capacitances of Activated Carbon Electrodes in $N$-Ethyl- $N$-methylpyrrolidinium Fluorohydrogenate Ionic Liquid. J. Electrochem. Soc. 2013, 160, A734-A738.

(19) Badway, F.; Mansour, A. N.; Pereira, N.; Al-Sharab, J. F.; Cosandey, F.; Plitz, I.; Amatucci, G. G. Structure and Electrochemistry of Copper Fluoride Nanocomposites Utilizing Mixed Conducting Matrices. Chem. Mater. 2007, 19, $4129-4141$.

(20) Dance, J. M.; Grannec, J.; Tressaud, A. Etude cristallochimique et magnétique de $\mathrm{Cs}_{2} \mathrm{CuF}_{4}$ : un ferromagnétique à caractère bidimensionnel. C. R. Acad. Sci. 1976, $283,115-118$.

(21) Riley, M. J.; Dubicki, L.; Moran, G.; Krausz, E. R.; Yamada, I. Optical Spectrum of $\mathrm{K}_{2} \mathrm{CuF}_{4}$. Inorg. Chem. 1990, 29, 1614-1626. 
(a)<smiles>F[CH-]F</smiles>

(b)

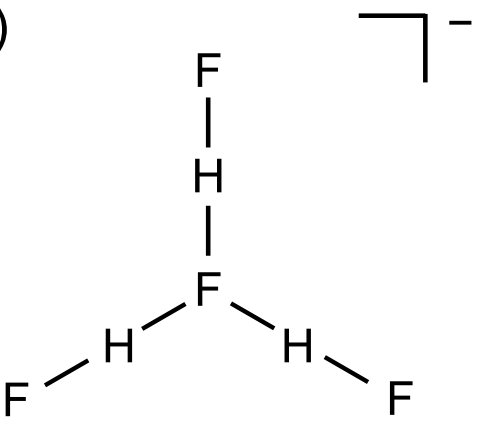

(c)

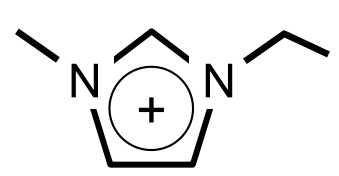

Figure 1 Structure of $(\mathrm{a}, \mathrm{b})$ fluorohydrogenate anions $\left(\left[(\mathrm{FH})_{n} \mathrm{~F}\right]^{-} ; n=2\right.$ and 3$)$ and $(\mathrm{c})$ 1-ethyl-3-methylimidazolium $\left(\left[\mathrm{C}_{2} \mathrm{C}_{1} \mathrm{im}\right]^{+}\right)$cation. 
(a)

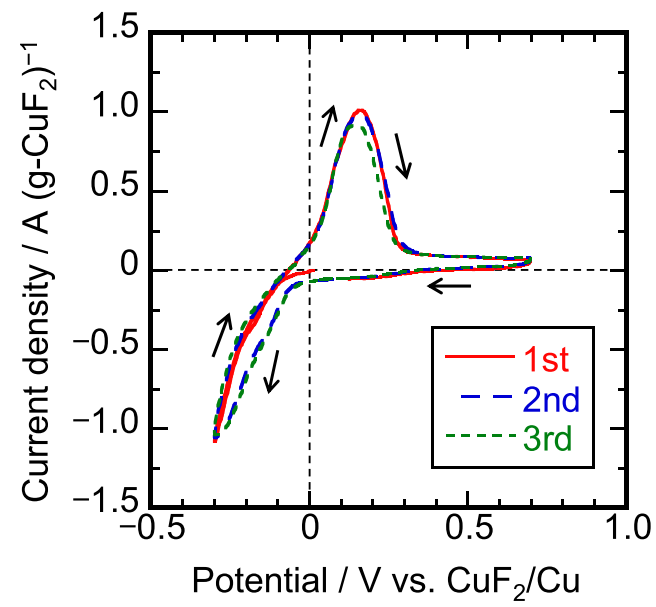

(b)

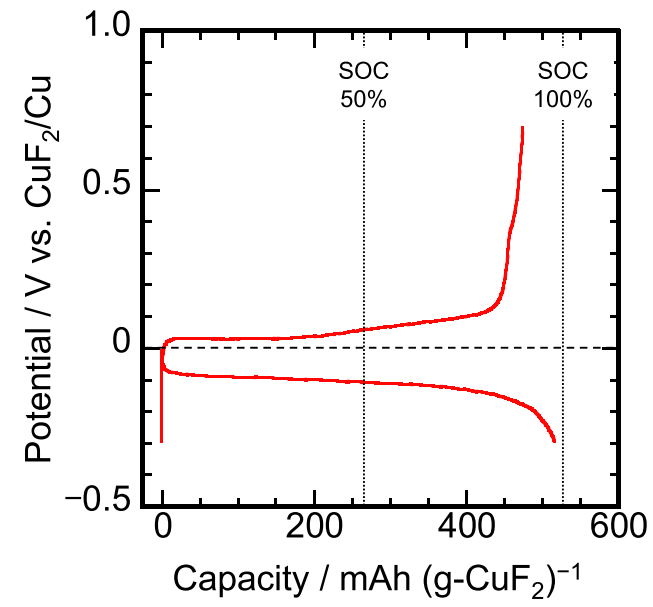

Figure 2 (a) Cyclic voltammograms and (b) subsequent charge-discharge curve of $\mathrm{CuF}_{2}$ electrode in $\left[\mathrm{C}_{2} \mathrm{C}_{1} \mathrm{im}\right]\left[(\mathrm{FH})_{2.3} \mathrm{~F}\right]$ at $298 \mathrm{~K}$. Scan rate: $10 \mathrm{mV} \mathrm{s}^{-1}$; charge-discharge rate: $0.05 \mathrm{C}\left(=26.4 \mathrm{~mA}\left(\mathrm{~g}-\mathrm{CuF}_{2}\right)^{-1}\right)$. The term, SOC (= state of charge), corresponds to the proportion of the capacity to the theoretical capacity. 




Figure $3 \mathrm{XRD}$ patterns of $\mathrm{CuF}_{2}$ electrodes at various charge-discharge states. (a) Pristine, (b) after discharging to $50 \%$ of the theoretical capacity $\left(264 \mathrm{mAh}\left(\mathrm{g}-\mathrm{CuF}_{2}\right)^{-1}\right)$, (c) after discharging to $-0.3 \mathrm{~V}$ vs. $\mathrm{CuF}_{2} / \mathrm{Cu},(\mathrm{d})$ after charging to $50 \%$ of the theoretical capacity $\left(264 \mathrm{mAh}\left(\mathrm{g}-\mathrm{CuF}_{2}\right)^{-1}\right)$, and (e) after charging to $0.7 \mathrm{~V}$ vs. $\mathrm{CuF}_{2} / \mathrm{Cu}$ in $\left[\mathrm{C}_{2} \mathrm{C}_{1} \mathrm{im}\right]\left[(\mathrm{FH})_{2.3} \mathrm{~F}\right]$ at $298 \mathrm{~K}$. 


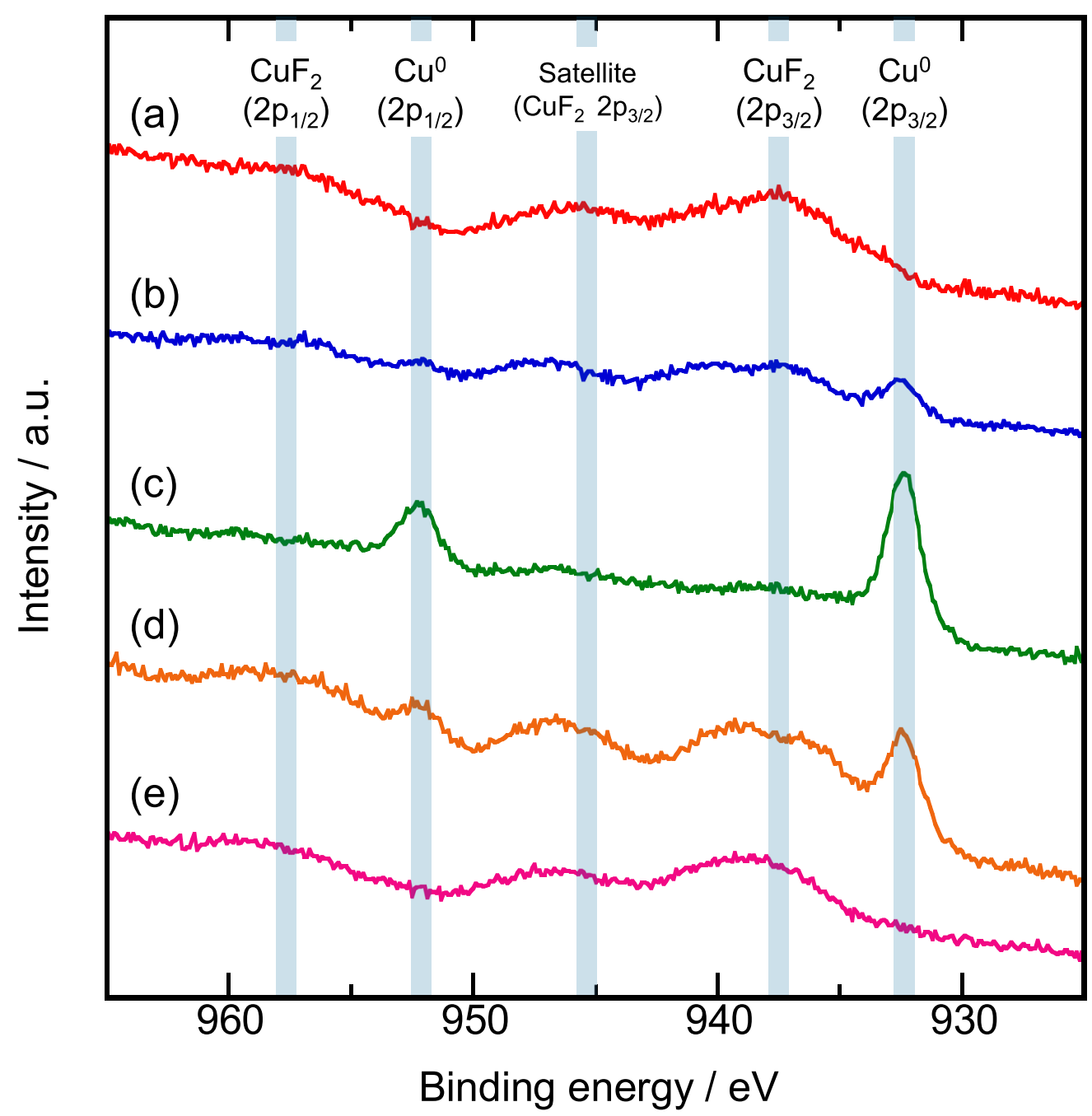

Figure 4 XPS profiles of $\mathrm{CuF}_{2}$ electrodes at various charge-discharge states. (a) Pristine, (b) after discharging to $50 \%$ of the theoretical capacity $\left(264 \mathrm{mAh}\left(\mathrm{g}-\mathrm{CuF}_{2}\right)^{-1}\right),(\mathrm{c})$ after discharging to $-0.3 \mathrm{~V}$ vs. $\mathrm{CuF}_{2} / \mathrm{Cu}$, (d) after charging to $50 \%$ of the theoretical capacity (264 $\left.\mathrm{mAh}\left(\mathrm{g}_{-}-\mathrm{CuF}_{2}\right)^{-1}\right)$, and (e) after charging to $0.7 \mathrm{~V}$ vs. $\mathrm{CuF}_{2} / \mathrm{Cu}$ in $\left[\mathrm{C}_{2} \mathrm{C}_{1} \mathrm{im}\right]\left[(\mathrm{FH})_{2.3} \mathrm{~F}\right]$ at $298 \mathrm{~K}$. 
Table of Contents (TOC) graphic

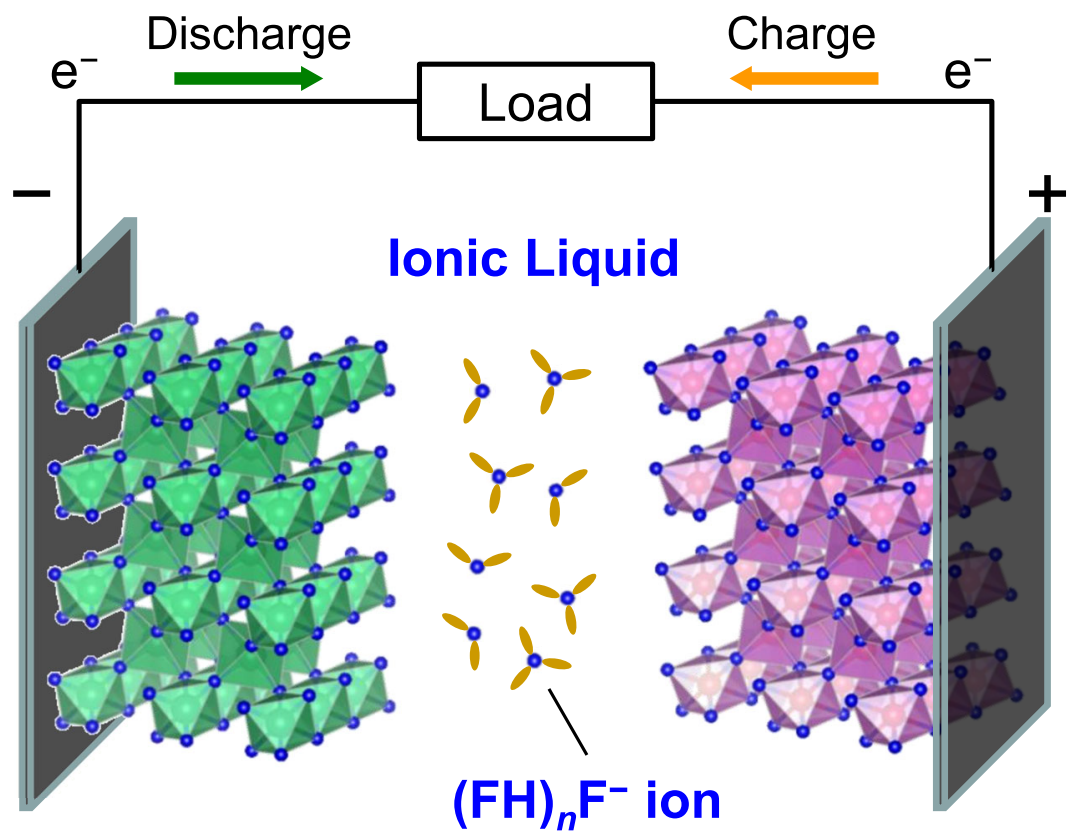

Negative electrode

Positive electrode $\mathrm{CuF}_{2}+4\left[(\mathrm{FH})_{3} \mathrm{~F}\right]^{-}+2 \mathrm{e}^{-} \rightleftharpoons \mathrm{Cu}+6\left[(\mathrm{FH})_{2} \mathrm{~F}\right]^{-}$ 


\section{Supporting Information}

Room-temperature fluoride shuttle batteries based on a fluorohydrogenate ionic liquid electrolyte

Takayuki Yamamoto,, ${ }^{1 *}$ Kazuhiko Matsumoto, ${ }^{2}$ Rika Hagiwara, ${ }^{2}$ and Toshiyuki Nohira $^{1, *}$

${ }^{1}$ Institute of Advanced Energy, Kyoto University, Gokasho, Uji 611-0011, Japan

${ }^{2}$ Graduate School of Energy Science, Kyoto University, Yoshida-honmachi, Sakyo-ku, Kyoto 606-8501, Japan

${ }^{*}$ Corresponding Authors:

*E-mail: $\quad$ yamamoto.takayuki.2w@kyoto-u.ac.jp, Tel: $\quad+81-774-38-3498, \quad$ Fax: +81-774-38-3499 (T. Y.).

*E-mail: $\quad$ nohira.toshiyuki.8r@kyoto-u.ac.jp, $\quad$ Tel: $\quad+81-774-38-3500, \quad$ Fax: +81-774-38-3499 (T. N.). 


\section{Experimental methods}

The fluorohydrogenate ionic liquid, $\left[\mathrm{C}_{2} \mathrm{C}_{1} \mathrm{im}\right]\left[(\mathrm{FH})_{2.3} \mathrm{~F}\right] \quad\left(\mathrm{C}_{2} \mathrm{C}_{1}\right.$ im $=$ 1-ethyl-3-methylimidazolium), and the precursor $\left[\mathrm{C}_{2} \mathrm{C}_{1} \mathrm{im}\right] \mathrm{Cl}$ were purchased from Morita Chemical Industries Co., Ltd. and Yoyulabo Co., Ltd., respectively.

To identify the existing phases of the $\mathrm{CuF}_{2}$ and $\mathrm{Cu}$ electrodes before and after charge-discharge tests, X-ray diffraction (XRD) analysis was performed using an X-ray diffractometer (Ultima IV, Rigaku Co.; $\mathrm{Cu}-\mathrm{K} \alpha$ radiation $(\lambda=0.15418 \mathrm{~nm})$ ) equipped with a $1 \mathrm{D}$ high-speed detector (D/teX Ultra, Rigaku Co.) with a nickel filter. The elemental compositions and chemical states of these electrodes were investigated by X-ray photoelectron spectroscopy (XPS; JPS-9010, JEOL) combined with argon ion etching. The accelerating voltage, current, and time of argon ion were $0.017-0.030 \mathrm{kV}$, $0.3 \mathrm{~mA}$, and 3-10 s, respectively. The surfaces were observed with a field emission scanning electron microscope (FE-SEM; SU-6600, Hitachi). Before the analysis, the electrochemical cells were disassembled and the remaining electrolytes on the surfaces of $\mathrm{CuF}_{2}$ and $\mathrm{Cu}$ electrodes were removed by soaking the samples in dehydrated and deoxidized ethanol (water content $<10 \mathrm{ppm}$, oxygen content $<1 \mathrm{ppm}$; Wako Pure Chemical Industries, Ltd.). These manipulations were conducted in the argon-filled glovebox. Finally, the samples were transferred to the analysis or work chambers of XRD, XPS and FE-SEM without air exposure.

Solubility of $\mathrm{CuF}_{2}$ in ionic liquid electrolytes was determined by inductively coupled plasma atomic emission spectroscopy (ICP-AES; SPECTRO BLUE, Hitachi) as follows. First, $\mathrm{CuF}_{2}$ powder was put into $\left[\mathrm{C}_{2} \mathrm{C}_{1} \mathrm{im}\right]\left[(\mathrm{FH})_{2.3} \mathrm{~F}\right]$ ionic liquid and stirred at $298 \mathrm{~K}$ for $24 \mathrm{~h}$. Then, the remaining powder was removed by filtering and the liquid was diluted by addition of $0.1 \mathrm{~mol} \mathrm{dm}^{-3}$ nitric acid aqueous solution. Finally, the 
concentration of copper in the solution was measured by ICP-AES.

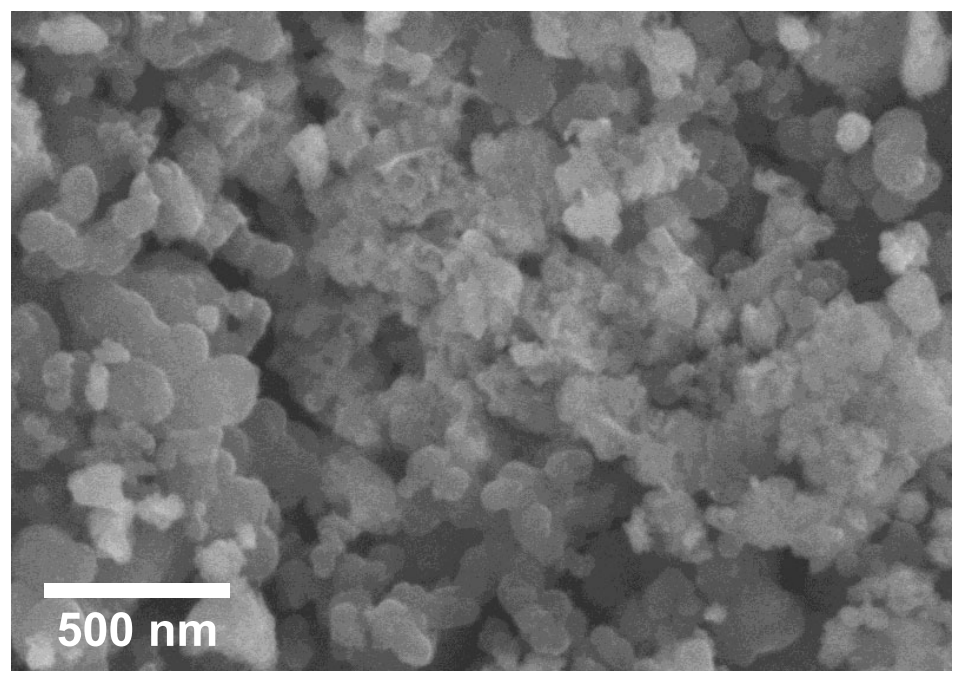

Figure S1 An SEM image of a pristine $\mathrm{CuF}_{2}$ electrode. 


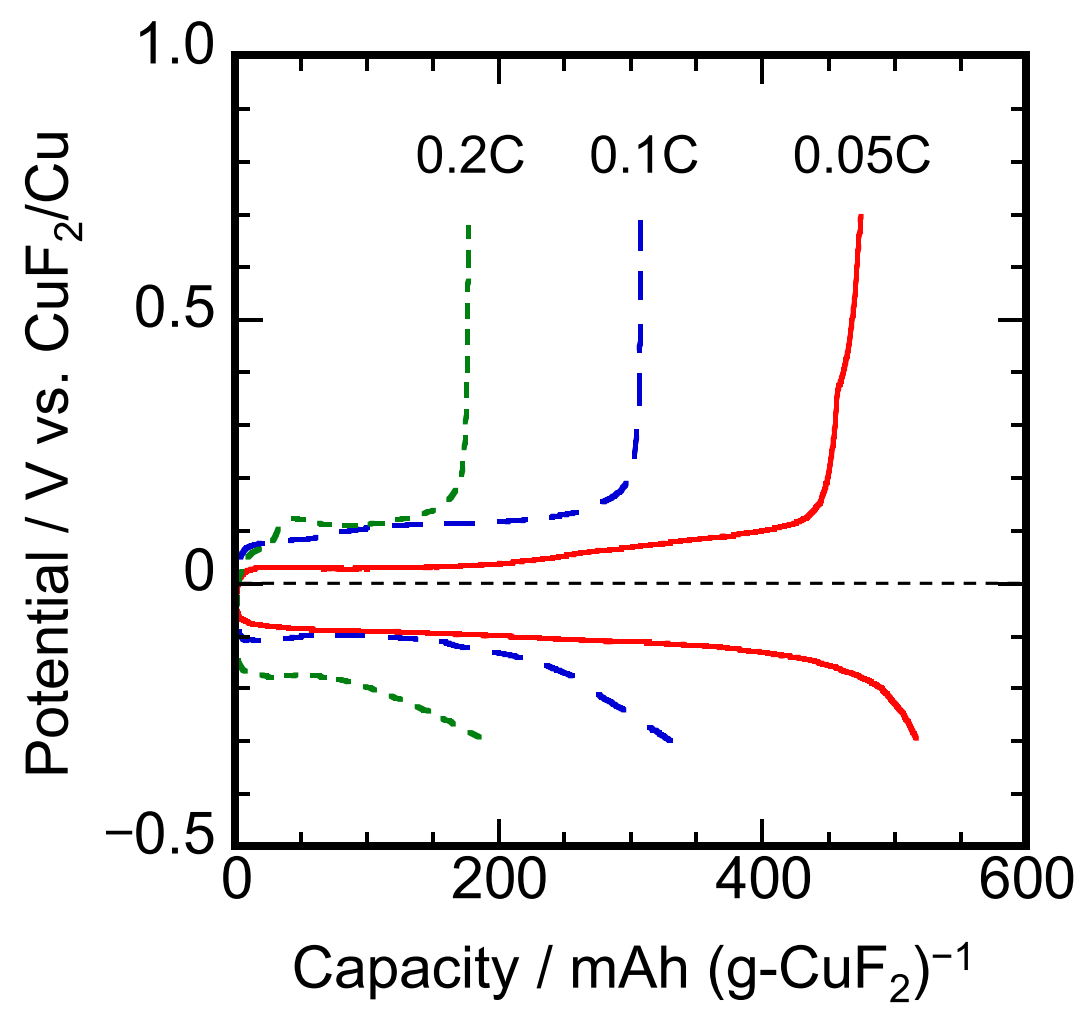

Figure S2 Initial charge-discharge curves at different charge-discharge rates $(0.05 \mathrm{C}$, $0.1 \mathrm{C}$, and $0.2 \mathrm{C})$ in $\left[\mathrm{C}_{2} \mathrm{C}_{1} \mathrm{im}\right]\left[(\mathrm{FH})_{2.3} \mathrm{~F}\right]$ at $298 \mathrm{~K}\left(1 \mathrm{C}\right.$ rate $\left.=528 \mathrm{~mA}\left(\mathrm{~g}-\mathrm{CuF}_{2}\right)^{-1}\right)$. 


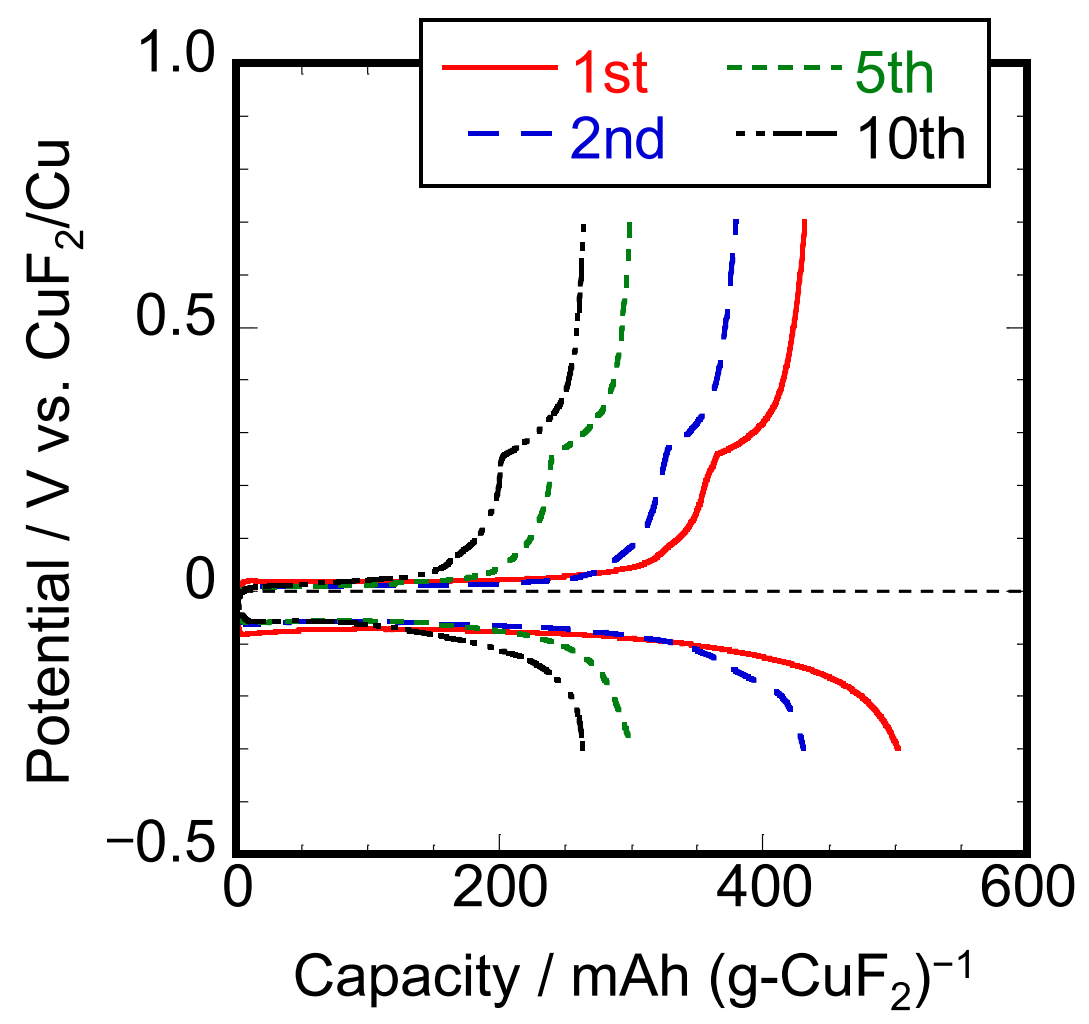

Figure S3 Charge-discharge curves of a $\mathrm{CuF}_{2}$ electrode at $0.05 \mathrm{C}$ rate in $\left[\mathrm{C}_{2} \mathrm{C}_{1} \mathrm{im}\right]\left[(\mathrm{FH})_{2.3} \mathrm{~F}\right]$ at $298 \mathrm{~K}\left(1 \mathrm{C}\right.$ rate $\left.=528 \mathrm{~mA}\left(\mathrm{~g}-\mathrm{CuF}_{2}\right)^{-1}\right)$. Cycle number: $1 \mathrm{st}, 2 \mathrm{nd}$, 5th, and 10th. 
(a)

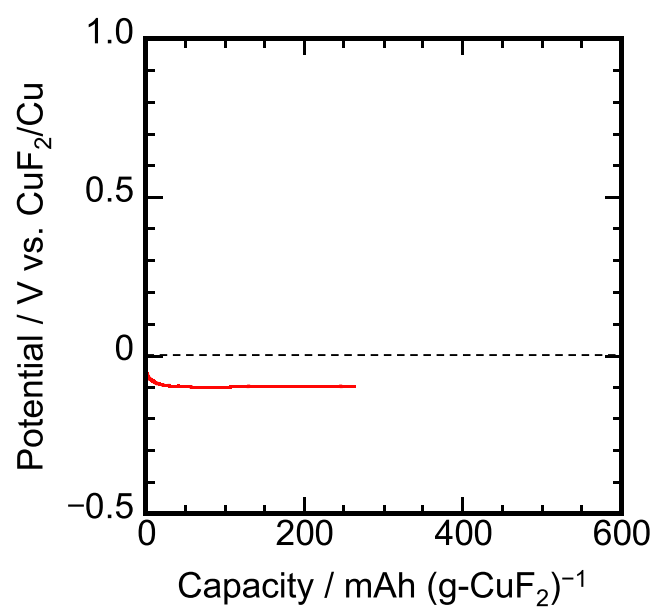

(c)

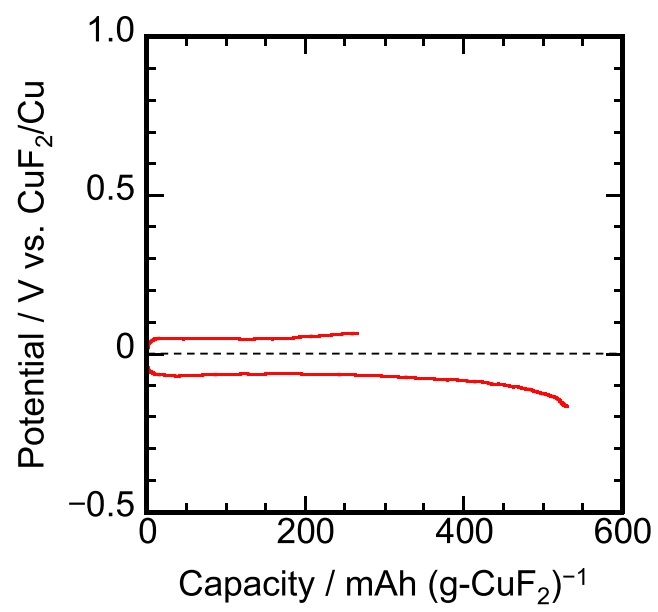

(b)

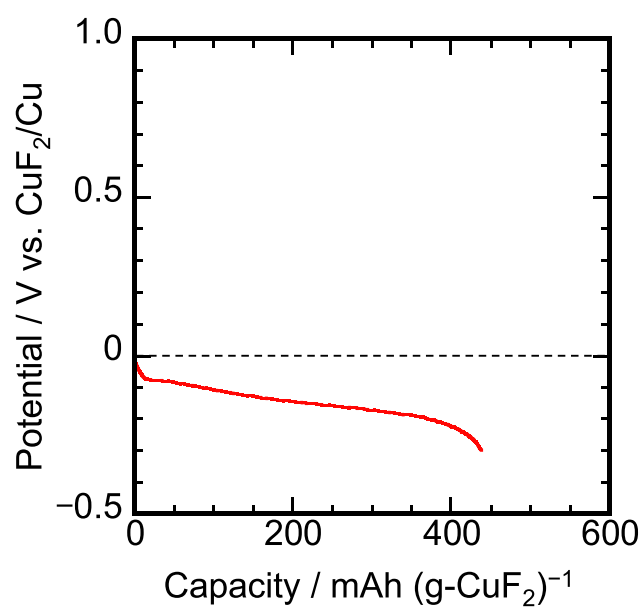

(d)

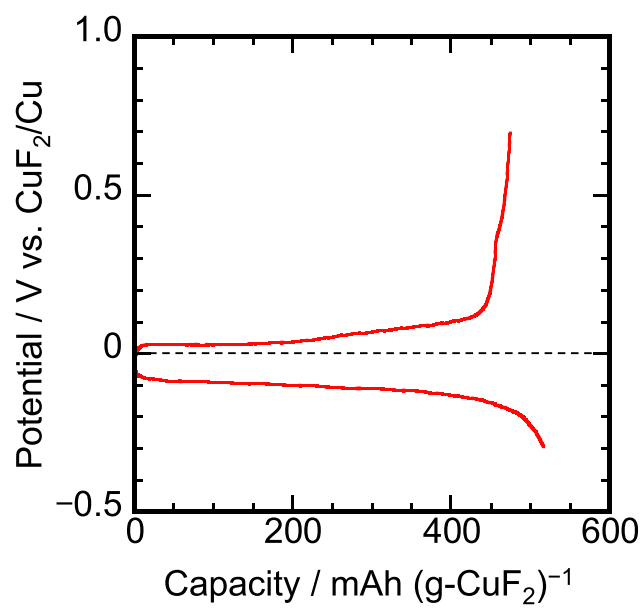

Figure S4 Charge-discharge curves of $\mathrm{CuF}_{2}$ electrodes in $\left[\mathrm{C}_{2} \mathrm{C}_{1} \mathrm{im}\right]\left[(\mathrm{FH})_{2.3} \mathrm{~F}\right]$ at $298 \mathrm{~K}$.

(a) Discharging to $50 \%$ of the theoretical capacity $\left(264 \mathrm{mAh}\left(\mathrm{g}-\mathrm{CuF}_{2}\right)^{-1}\right)$, discharging to $-0.3 \mathrm{~V}$ vs. $\mathrm{CuF}_{2} / \mathrm{Cu}$, (c) charging to $50 \%$ of the theoretical capacity (264 $\left.\mathrm{mAh}\left(\mathrm{g}-\mathrm{CuF}_{2}\right)^{-1}\right)$, and (d) charging to $0.7 \mathrm{~V}$ vs. $\mathrm{CuF}_{2} / \mathrm{Cu}$. Charge-discharge rate: $0.05 \mathrm{C}$ $\left(=26.4 \mathrm{~mA}\left(\mathrm{~g}-\mathrm{CuF}_{2}\right)^{-1}\right) .(\mathrm{d})$ is the same figure as Figure $\mathbf{2 b}$. 




Figure S5 A charge curve of a $\mathrm{Cu}$ electrode in $\left[\mathrm{C}_{2} \mathrm{C}_{1}\right.$ im $]\left[(\mathrm{FH})_{2.3} \mathrm{~F}\right]$ at $298 \mathrm{~K}$ at $0.02 \mathrm{C}$ rate $\left(=16.9 \mathrm{~mA}(\mathrm{~g}-\mathrm{Cu})^{-1}\right)$. 


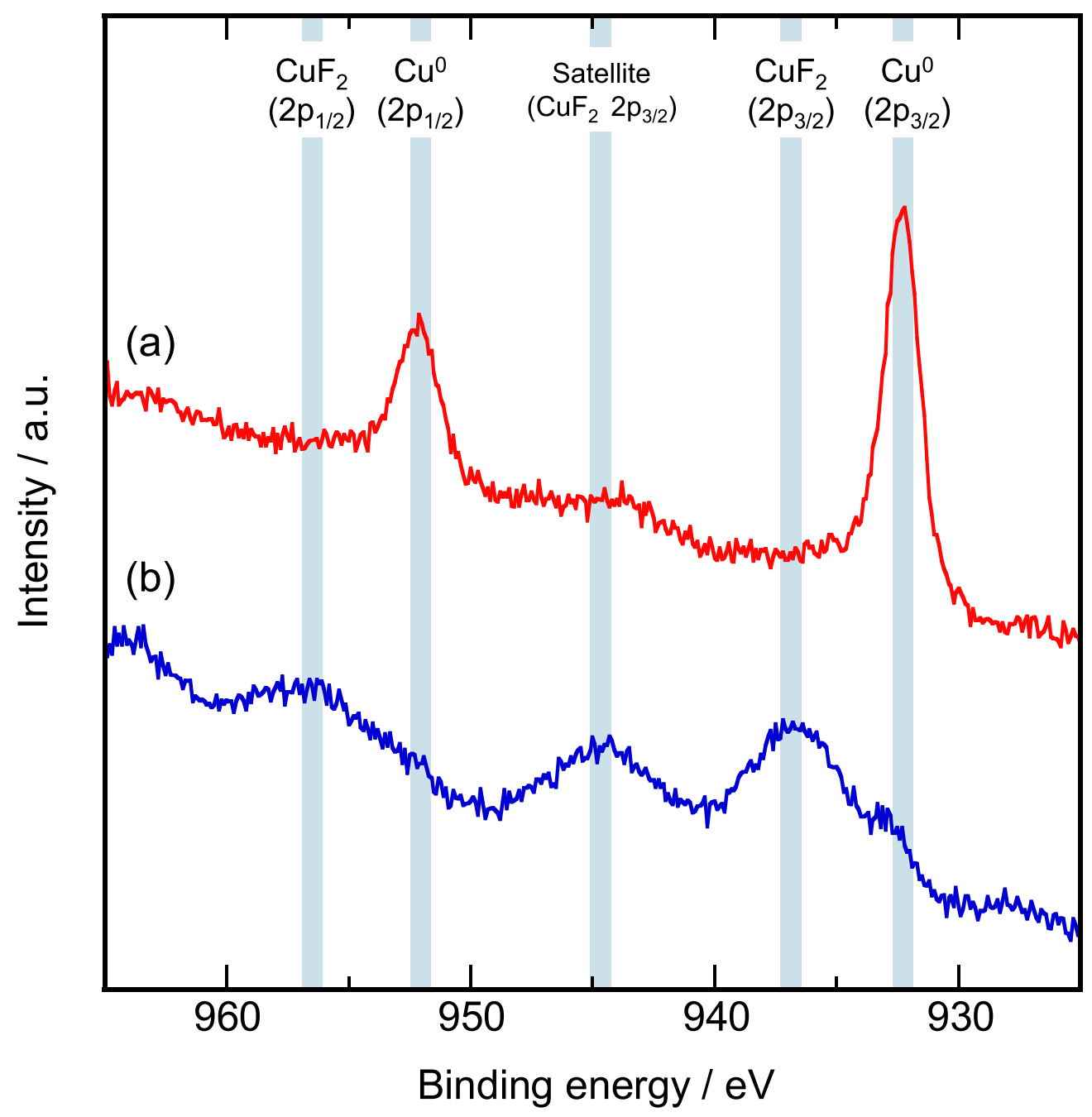

Figure S6 XPS spectra for (a) the pristine and (b) the charged $\mathrm{Cu}$ electrodes. 